\title{
Weed control in establishing mixed swards of clover, plantain and chicory
}

\author{
T.L. Gawn, K.C. Harrington and C. Matthew \\ Institute of Natural Resources, Massey University, Private Bag 11-222, \\ Palmerston North 4442, New Zealand \\ Corresponding author: K.Harrington@massey.ac.nz
}

\begin{abstract}
A field trial was conducted in Palmerston North to assess weed control options for establishing mixed swards of chicory (Cichorium intybus), narrow-leaved plantain (Plantago lanceolata), red clover (Trifolium pratense) and white clover (Trifolium repens), a pasture mixture currently popular for finishing lambs. Haloxyfop safely controlled grass weeds, and mowing twice during the first few months of establishment helped control some broad-leaved weeds. Flumetsulam was the safest herbicide for controlling broad-leaved weeds, although it caused severe suppression of plantain initially. All other treatments caused unacceptable levels of damage to at least one of the sown species. If chicory was not included in the mix, then bentazone, paraquat/diquat and diuron could be used. Options for an integrated weed control programme for the mixture of four species are discussed. For young clover-based pastures, hemlock (Conium maculatum) will be controlled better by flumetsulam or bentazone than 2,4-DB.
\end{abstract}

Keywords plantain, Plantago lanceolata, chicory, Cichorium intybus, white clover, Trifolium repens, red clover, Trifolium pratense, herbicides, mowing, hemlock.

\section{INTRODUCTION}

Narrow-leaved plantain (Plantago lanceolata, hereafter referred to as plantain) and chicory (Cichorium intybus) are both mineralrich perennial herbs that tolerate drought and prevent bloat, and thus provide high quality feed for summer periods when they are used to finish lambs (Stewart 1996; Barry 1998). Trials on the use of narrow-leaved plantain and chicory grown with red clover (Trifolium pratense) and white clover (Trifolium repens) have shown that the mixture can provide lamb and sheep production superior to that from pastures based on perennial ryegrass (Lolium perenne) (Kenyon et al. 2010; Golding et al. 2011; Hutton et al. 2011).
As high levels of production are required when growing specialty swards such as this mixture for finishing livestock, it is important that weeds are removed. Although information exists on herbicides that can safely control weeds present in any of these pasture species grown alone, there is almost no information on which herbicides are safe when all four species are grown together.

A number of herbicides are registered for use in red and white clover, such as MCPB, bentazone, flumetsulam, paraquat, diquat, haloxyfop and imazethapyr (Young 2012). Less is known about herbicide effects on chicory and plantain. Hare et al. (1993) found bentazone was tolerated by older seedlings, while mature plants tolerated paraquat, 
diuron, metribuzin and low rates of 2,4-DB. Rowarth (1998) stated that plantain seedlings are tolerant of diuron, paraquat, diquat, bentazone, haloxyfop and dicamba. Lockley \& Wu (2008) found that plantain and chicory seedlings had some tolerance of 2,4-DB and diuron.

The objective of this field trial was to assess the relative safety and efficacy of a number of post-emergence treatments for controlling weeds in a newly established sward of plantain, chicory, red clover and white clover.

\section{MATERIALS AND METHODS}

A field trial was set up on the Massey University Pasture and Crop Research Unit at Poultry Farm Road, Palmerston North, on a Manawatu fine sandy loam. A paddock was prepared by spraying with glyphosate followed by mouldboard ploughing and secondary cultivation. Puna II chicory (6 kg/ha), Tonic plantain $(6 \mathrm{~kg} / \mathrm{ha})$, Sensation red clover ( $6 \mathrm{~kg} / \mathrm{ha})$ and Bounty white clover $(4 \mathrm{~kg} / \mathrm{ha})$ were sown on 14 March 2011 with a V-ring roller drill. Cropmaster 15 fertiliser $(15.2 \% \mathrm{~N}, 10 \%$ $\mathrm{P}, 10 \% \mathrm{~K}$ and $7.7 \% \mathrm{~S}$ ) was applied at $250 \mathrm{~kg} / \mathrm{ha}$. Weeds that established among the sown plants included broad-leaved dock (Rumex obtusifolius), clustered dock (Rumex conglomeratus), hemlock (Conium maculatum), black nightshade (Solanum nigrum), fathen (Chenopodium album), annual poa (Poa annua), perennial ryegrass (Lolium perenne) and prairie grass (Bromus willdenowii).
The trial site was divided into $3 \mathrm{~m} \times 4$ m plots and 12 treatments (Table 1 ) were applied to plots on 22 April 2011 using a randomised block design, with blocking used to allow for differences across the site in weed densities and crop establishment. All treatments were applied with a precision plot sprayer pressurised by carbon dioxide with Teejet 730231 flat-fan nozzles. Treatments 3 to 12 were sprayed with haloxyfop at $200 \mathrm{~g}$ ai/ha in 250 litres/ha water immediately prior to application of the herbicides listed in Table 1. At the time of spraying, pasture plants were all at about 2-4 true leaf stage and weeds were forming canopies $15-20 \mathrm{~cm}$ high in places and beginning to shade the crop plants. The mowing for Treatment 3 was conducted with a lawn mower set at a cutting height of $8 \mathrm{~cm}$, and occurred on 2 May 2011 once the haloxyfop had translocated throughout the grass weeds, then again on 1 July 2011. All plots were grazed by ewes in mid-June and midSeptember, so the second mowing trimmed plants such as hemlock that were not eaten by the sheep.

The effect of treatments on crop and weed plants was assessed using a scoring method for each species in each plot on ten occasions during 2011, with the first assessment 2 weeks after application and the final one after 32 weeks. The scoring used a linear scale from 0 (all plants dead) to 10 (all plants appearing healthy across the whole plot). The botanical composition in each plot was also assessed on 10 June 2011 by

Table 1 Treatments applied to young plantain/chicory/clover sward.

\begin{tabular}{|c|c|c|c|}
\hline Treatment & Trade name & $\mathrm{g}$ ai/ha & Water rate (litres/ha) \\
\hline \multicolumn{4}{|l|}{ 1. untreated control } \\
\hline 2. haloxyfop only & Gallant NF & 200 & 250 \\
\hline \multicolumn{4}{|l|}{ 3. mowing 1} \\
\hline 4. flumetsulam ${ }^{1}$ & Preside & 40 & 250 \\
\hline 5. flumetsulam ${ }^{1}$ & Preside & 52 & 250 \\
\hline 6. flumetsulam + oil $^{1}$ & Preside + Uptake & $40(+1.25$ litres/ha $)$ & 250 \\
\hline 7. flumetsulam + oil $^{1}$ & Preside + Uptake & $52(+1.25$ litres/ha $)$ & 250 \\
\hline 8. $2,4-\mathrm{DB}^{1}$ & Dow AgroSciences 2,4-DB & 2400 & 250 \\
\hline 9. diflufenican ${ }^{1}$ & Quantum & 100 & 250 \\
\hline 10. diuron ${ }^{1}$ & Karmex & 400 & 500 \\
\hline 11. bentazone $e^{1}$ & Basagran & 1440 & 500 \\
\hline 12. paraquat + diquat $^{1}$ & Preeglone & $270+230$ & 500 \\
\hline
\end{tabular}

${ }^{1}$ Haloxyfop was applied to these treatments at $200 \mathrm{~g} / \mathrm{ha}$ on 22 April 2011. 
Table 2 Scores $(0=$ dead, $10=$ healthy) for plantain, chicory and clovers at 4 and 32 weeks after herbicide application, and dry matter of plantain, chicory and clovers 7 weeks after herbicide application.

\begin{tabular}{|c|c|c|c|c|c|c|c|c|c|}
\hline \multirow[b]{3}{*}{ Treatment } & \multicolumn{6}{|c|}{ Scores after 4 and 32 weeks } & & & \\
\hline & \multicolumn{2}{|c|}{ Plantain } & \multicolumn{2}{|c|}{ Chicory } & \multicolumn{2}{|c|}{ Clovers } & \multicolumn{3}{|c|}{ DM (kg/ha) after 7 weeks } \\
\hline & 4 & 32 & 4 & 32 & 4 & 32 & Plantain & Chicory & Clovers \\
\hline untreated control & 7.3 & 5.8 & 7.3 & 5.0 & 6.5 & 2.8 & 88 & 82 & 3 \\
\hline haloxyfop only & 6.8 & 5.8 & 7.3 & 4.8 & 5.3 & 4.0 & 86 & 147 & 3 \\
\hline mowing & 7.5 & 7.8 & 4.3 & 4.0 & 6.8 & 6.5 & 840 & 327 & 18 \\
\hline flumetsulam (low) & 0.8 & 7.0 & 8.0 & 7.3 & 8.5 & 8.3 & 42 & 1200 & 57 \\
\hline flumetsulam (high) & 0.8 & 5.5 & 7.3 & 7.5 & 8.0 & 7.8 & 11 & 1004 & 69 \\
\hline flumetsulam (L)+oil & 0.8 & 6.5 & 7.5 & 7.8 & 8.0 & 8.3 & 8 & 1117 & 40 \\
\hline flumetsulam $(\mathrm{H})+$ oil & 1.5 & 6.8 & 7.0 & 7.8 & 8.0 & 9.0 & 27 & 946 & 32 \\
\hline $2,4-\mathrm{DB}$ & 1.5 & 3.5 & 4.0 & 4.5 & 6.5 & 7.8 & 46 & 178 & 28 \\
\hline diflufenican & 4.0 & 5.5 & 3.8 & 4.3 & 4.8 & 6.0 & 146 & 33 & 26 \\
\hline diuron & 8.8 & 8.5 & 1.5 & 0.0 & 7.0 & 5.5 & 1445 & 21 & 25 \\
\hline bentazone & 7.0 & 8.3 & 0.5 & 0.0 & 8.0 & 7.8 & 1008 & 10 & 51 \\
\hline paraquat/diquat & 6.5 & 8.0 & 0.0 & 0.0 & 6.0 & 7.3 & 1108 & 0 & 13 \\
\hline $\operatorname{LSD}(\mathrm{P}=0.05)$ & 1.2 & 1.8 & 1.6 & 1.4 & 1.6 & 1.6 & 360 & 446 & 42 \\
\hline
\end{tabular}

cutting all vegetation from two randomly selected $0.1 \mathrm{~m}^{2}$ quadrats per plot, separating all species and measuring their dry weights. An analysis of variance was performed on all data using SAS, and least significant differences were calculated to test if treatment means differed significantly.

\section{RESULTS}

Weed competition resulted in plantain, chicory and clovers being significantly less healthy in untreated plots and those sprayed only with haloxyfop, which removed only grass weeds, and this effect was most noticeable for the clover component within plots (Table 2). Mowing helped to reduce this suppression of the plantain and clovers, although chicory failed to regrow strongly after the second mowing, presumably due to slow growth rates of this species in winter.

None of the herbicides with activity against broad-leaved weeds were tolerated well by all four pasture species. The most promising was flumetsulam, which was tolerated well by the chicory and clovers, but plantain suffered a severe initial check in growth (Table 2). This adverse effect on the plantain was no less severe at the lower rate used or when oil was not added to the herbicide to improve penetration. However the plantain did recover from all four flumetsulam treatments after about 3 months, resulting in a good balance of chicory, plantain and clover when the trial ended after 32 weeks in early December 2011.

Of the other herbicide treatments, 2,4-DB and diflufenican were too damaging to both the plantain and chicory, while diuron, bentazone and the paraquat/diquat mixture were too damaging to chicory (Table 2). Difficulty in differentiating between young plants of white clover and red clover for both scoring and sorting of plants for dry weight measurements meant differences between these two clover species in susceptibility to herbicides could not be measured, though 2,4-DB is known to damage young red clover (Young 2012).

Although mowing gave good control of upright annual weed species, such as black nightshade and fathen, it caused only temporary suppression of the hemlock and the dock species (Table 3) because their growing points are at ground level like the chicory, plantain and clovers. The flumetsulam gave good suppression of the dock and hemlock, although it did not kill these plants, nor did it have much effect on the black nightshade. However, this level of suppression was sufficient to allow good establishment of the planted species. The higher rate of flumetsulam with oil added appeared to reduce the dry weight 
of hemlock best when measured after 7 weeks, and had some effect on the black nightshade.

All black nightshade and fathen plants were gone by the end of the trial as these summer annuals died naturally over winter and could not re-establish in spring within the dense grazed swards.

The paraquat/diquat mix killed all weeds, leaving a weed-free sward of plantain and clover. The hemlock was controlled well by bentazone and the docks were severely suppressed by $2,4-$ DB. Haloxyfop removed grass weeds successfully across all treatments though some were beginning to reappear by the end of the trial.

\section{DISCUSSION}

The overall aim of this work was to allow establishment of swards that had good numbers of plantain, chicory and clover plants growing side by side. Animal scientists at Massey University are currently assessing whether such a mixture will give better animal production than simply having pure swards of plantain, chicory or clover (Golding et al. 2011). Although it initially appears that no herbicide other than haloxyfop is suitable for weed control in a mixture of chicory, plantain and clovers, the flumetsulam treatments did give a balanced mix of these species by the end of the trial despite the initial suppression of plantain seedlings. This suppression may be useful as plantain often grows too aggressively at early stages in the establishment of these mixed swards, and Table 2 shows chicory and clovers dominated 7 weeks after herbicide application in flumetsulam plots, no doubt assisted by this reduced early competition from plantain.

Flumetsulam might also be expected to cause less damage to plantain if application is delayed longer than 5 weeks after sowing as occurred in this trial. This herbicide is routinely used at Massey University for weed control in established plantain crops without adverse effects. Thus the most effective weed control strategy in young swards of plantain, chicory and clovers may be to apply haloxyfop early for grass weed control, use mowing about 6 weeks after sowing for initial broad-leaved weed control, then apply flumetsulam once the plantain plants are several months old. Grazing pressure and competition from rapid crop establishment are other techniques that could be used as part of an integrated weed management programme. Many of the weed species within the

Table 3 Scores ( $0=$ dead, $10=$ healthy) for hemlock, broad-leaved dock and black nightshade at 4 and 32 weeks after herbicide application, and dry matter of these weeds 7 weeks after herbicide application.

\begin{tabular}{|c|c|c|c|c|c|c|c|c|c|}
\hline \multirow[b]{3}{*}{ Treatment } & \multicolumn{6}{|c|}{ Scores after 4 and 32 weeks } & & & \\
\hline & \multicolumn{2}{|c|}{ Hemlock } & \multicolumn{2}{|c|}{ Dock } & \multicolumn{2}{|c|}{ Nightshade } & \multicolumn{3}{|c|}{ DM (kg/ha) after 7 weeks } \\
\hline & 4 & 32 & 4 & 32 & 4 & 32 & Hemlock & Dock & Nightshade \\
\hline untreated control & 10.0 & 6.3 & 10.0 & 8.0 & 8.3 & 0.0 & 351 & 773 & 247 \\
\hline haloxyfop only & 10.0 & 7.8 & 10.0 & 7.3 & 10.0 & 0.0 & 620 & 358 & 620 \\
\hline mowing & 7.5 & 3.5 & 7.5 & 4.8 & 0.5 & 0.0 & 277 & 185 & 9.5 \\
\hline flumetsulam (low) & 2.5 & 3.5 & 5.8 & 5.3 & 7.8 & 0.0 & 40 & 46 & 244 \\
\hline flumetsulam (high) & 4.0 & 3.3 & 4.5 & 6.3 & 7.3 & 0.0 & 21 & 81 & 304 \\
\hline flumetsulam (L)+oil & 3.8 & 3.3 & 7.8 & 5.5 & 8.0 & 0.0 & 10 & 99 & 333 \\
\hline flumetsulam $(\mathrm{H})+$ oil & 3.8 & 0.8 & 5.5 & 4.5 & 8.0 & 0.0 & 0.2 & 53 & 94 \\
\hline 2,4-DB & 8.3 & 9.3 & 1.3 & 5.5 & 0.8 & 0.0 & 1006 & 22 & 0.0 \\
\hline diflufenican & 8.8 & 8.0 & 7.5 & 7.8 & 5.5 & 0.0 & 720 & 240 & 13 \\
\hline diuron & 7.5 & 4.5 & 8.8 & 5.8 & 0.8 & 0.0 & 210 & 151 & 0.1 \\
\hline bentazone & 1.5 & 0.8 & 9.0 & 5.0 & 5.5 & 0.0 & 28 & 320 & 105 \\
\hline paraquat/diquat & 0.0 & 0.3 & 0.3 & 2.5 & 0.0 & 0.0 & 0.0 & 2.8 & 0.0 \\
\hline $\operatorname{LSD}(\mathrm{P}=0.05)$ & 1.9 & 1.9 & 2.2 & 1.6 & 2.0 & - & 329 & 303 & 261 \\
\hline
\end{tabular}


sward, such as grasses, docks and upright annuals, will be eaten by sheep (Popay \& Field 1996). Once a crop is established, new weed seedlings are easily outcompeted by these larger plants (Swanton \& Weise 1991).

Flumetsulam does not control a number of broad-leaved weed species, especially Asteraceae weeds such as thistles and ragwort (Young 2012). Few of these weeds were present in the trial, but in a situation where these were the main weeds present, having to rely on just flumetsulam for broad-leaved weed control could be a problem. Also, for many weeds, flumetsulam needs to be applied while they are young seedlings, so delaying application may reduce weed control.

Although the other herbicides assessed in this trial appear unsuitable for use in mixtures of plantain, chicory and clovers, some such as diuron may be useful for swards of these species once the chicory is older and better able to tolerate the chemicals. Results from this trial highlighted a number of useful chemicals for farmers wanting to grow plantain/clover mixtures without chicory, especially the paraquat/diquat mixture, bentazone and diuron. The highest total dry matter of sown species within Table 1 occurred in plots sprayed with diuron due to the superior early growth of plantain. However, pure plantain swards will not necessarily give the same animal growth rates throughout the year as the mixed sward without chicory's deep root system that gives superior summer growth and the high nutritive value of clovers (Golding et al. 2001).

Some useful results were also obtained from this trial to assist with weed control in young ryegrass/clover swards, especially with hemlock for which weed control information is sparse. Both bentazone and flumetsulam look useful for controlling hemlock in young pastures, while docks were initially suppressed well by 2,4-DB and flumetsulam when compared with untreated plots.

\section{ACKNOWLEDGEMENTS}

The authors wish to thank Mark Osborne for technical assistance in the setting up and running of this trial.

\section{REFERENCES}

Barry TN 1998. The feeding value of chicory (Cichorium intybus) for ruminant livestock. Journal of Agricultural Science, Cambridge 131: 251-257.

Golding KP, Wilson ED, Kemp PD, Pain SJ, Kenyon PR, Morris ST, Hutton PG 2011. Mixed herb and legume pasture improves the growth of lambs post-weaning. Animal Production Science 51: 717-723.

Hare MD, Rolston MP, Foote AG, Archie WJ, Hagerty G 1993. Herbicide tolerance of Grasslands Puna chicory. Proceedings of the $46^{\text {th }}$ New Zealand Plant Protection Conference: 282-287.

Hutton PG, Kenyon PR, Bedi MK, Kemp PD, Stafford KJ, West DM, Morris ST 2011. A herb and legume sward mix increased ewe milk production and ewe and lamb live weight gain to weaning compared to a ryegrass dominant sward. Animal Feed Science and Technology 164: 1-7.

Kenyon PR, Kemp PD, Stafford KJ, West DM, Morris ST 2010. Can a herb and white clover mix improve the performance of multiplebearing ewes and their lambs to weaning? Animal Production Science 50: 513-521.

Lockley P, Wu H 2008. Herbicide tolerance in pasture legumes and herbs. Proceedings of the $16^{\text {th }}$ Australian Weeds Conference: 319-322.

Popay I, Field R 1996. Grazing animals as weed control agents. Weed Technology 10: 217-231.

Rowarth JS 1998. Plantain. In: Rowarth JS ed. Practical herbage seedcrop management. Lincoln University Press, Lincoln, New Zealand. Pp.189-193.

Stewart AV 1996. Plantain (Plantago lanceolata) a potential pasture species. Proceedings of the New Zealand Grassland Association 58: 77-86.

Swanton CJ, Weise SF 1991. Integrated weed management: the rationale and approach. Weed Technology 5: 657-663.

Young S 2012. New Zealand Novachem agrichemical manual. AgriMedia Ltd, Christchurch, New Zealand. 723 p. 